\title{
Acetylcholinesterase inhibition and cytotoxicity of flavonoids and chalcones from Derris indica
}

\author{
Thurdpong Sribuhom ${ }^{\mathrm{a}}$, Chalotorn Saraphon ${ }^{\mathrm{a}}$, Phatharapoll Decharchoochart ${ }^{\mathrm{a}}$, \\ Chantana Boonyarat ${ }^{\mathrm{b}}$, Chavi Yenjai ${ }^{\mathrm{a}, *}$ \\ ${ }^{a}$ Natural Products Research Unit, Department of Chemistry and \\ Centre of Excellence for Innovation in Chemistry, Faculty of Science, Khon Kaen University, \\ Khon Kaen 40002 Thailand \\ b Faculty of Pharmaceutical Sciences, Khon Kaen University, Khon Kaen 40002 Thailand
}

*Corresponding author, e-mail: chayen@kku.ac.th

Received 29 Dec 2015

Accepted 11 Sep 2016

\begin{abstract}
Derris indica, a Thai medicinal plant, contains biologically active substances such as flavone, flavanone, chalcone, and rotenoid compounds. Many compounds from this plant show antitumour, antihyperglycaemic, and anti-inflammatory activities. In this study, eleven compounds including six flavonoid and five chalcone compounds were isolated from the seed of $D$. indica. Their structures were established on the basis of NMR spectroscopic data. Desmethoxykanugin showed 100\% inhibition to acetylcholinesterase, being about two fold stronger than the standard, tacrine, but cytotoxic against normal cells. Fortunately, pongaflavone and (2R,3R)-3-hydroxy-5-methoxy$2^{\prime \prime}, 2^{\prime \prime}$-dimethylpyrano[7,8:5",6" $]$-flavanone displayed around 50\% inhibition to AChE as compared to the standard and they were inactive against normal cells. Thus these compounds could be developed to treat Alzheimer's disease. In addition, candidone, pongamol, obovatachalcone, derrischalcone, and tunicatachalcone showed cytotoxic activity against $\mathrm{KB}$ cell line with $\mathrm{IC}_{50}$ values ranging from 8-18 $\mu \mathrm{g} / \mathrm{ml}$.
\end{abstract}

KEYWORDS: Alzheimer's disease, KB cells, desmethoxykanugin, pongaflavone, pongamol

\section{INTRODUCTION}

Alzheimer's disease is a neurodegenerative disease which causes loss of memory, language skills, attention, and depression. This disease affects millions of elderly people ${ }^{1}$. Although the aetiology is not well understood, it is believed that the deposition of $\beta$-amyloid plaques, a low level of acetylcholine (ACh), formation of neurofibrillary tangles containing tau protein, and oxidative stress may cause this disease ${ }^{2}$. Acetylcholinesterase (AChE) is an enzyme that hydrolizes the ester bond of ACh. The inhibition of AChE results in a rising ACh level in the brain ${ }^{3}$. Thus an AChE inhibitor is one of the strategies that is used to treat Alzheimer's disease. Nowadays the AChE inhibitors which are usually used with patients are tacrine, serine, donepezil, rivastigamine, and galantamine. However, these agents show side effects such as diarrhoea, nausea, and vomiting ${ }^{4}$. For this reason the search for AChE inhibitors from natural sources is still necessary.

Derris indica, belonging to the Fabaceae family, is known as 'yi-nam' in Thai and as 'karanj' or 'karanja' in Hindi ${ }^{5}$. This plant is a mangrove tree and grows widely throughout Southeast Asia and the Pacific Islands. The leaves have five or seven leaflets, pinkish-white flowers and thin grey bark. This medicinal plant has been used for bronchitis, whooping cough, rheumatic arthritis, ulcers, and diabetes $^{6}$. It has been reported that this plant contains biologically active substances such as flavone, flavanone, chalcone, and rotenoid compounds ${ }^{7}$. The seed and seed oil have been used to treat inflammatory and infectious diseases and for tanning leather and making soap. Nowadays the seed oil is used as a fuel in diesel engines and shows a good thermal efficiency ${ }^{8}$. In the present study, we focus on the evaluation of AChE inhibition and cytotoxic activities of all compounds found in the seed of D. indica.

\section{MATERIALS AND METHODS}

\section{General experimental procedures}

Melting points were determined on an SANYO Gallenkamp (UK) melting point apparatus and are uncorrected. UV spectra were measured on an Agilent 8453 UV-Vis spectrophotometer (Germany). IR spectra were recorded as $\mathrm{KBr}$ disks or thin films, using a Perkin Elmer Spectrum One FT-IR spectropho- 
tometer (UK). The NMR spectra were recorded on a Varian Mercury plus spectrometer (UK) operating at $400 \mathrm{MHz}\left({ }^{1} \mathrm{H}\right)$ and at $100 \mathrm{MHz}\left({ }^{13} \mathrm{C}\right)$. Mass spectra were determined on a Micromass Q-TOF 2 hybrid quadrupole time-of-flight mass spectrometer with a Z-spray ES source (Micromass, Manchester, UK). Optical rotation was obtained using a JASCO DIP1000 digital polarimeter. Thin layer chromatography (TLC) was carried out on MERCK silica gel 60 F254 TLC aluminium sheets. Column chromatography was done with silica gel $0.063-0.200 \mathrm{~mm}$ or less than $0.063 \mathrm{~mm}$. Preparative layer chromatography was carried out on glass supported silica gel plates using silica gel 60 PF254. All solvents were routinely distilled prior to use.

\section{Plant material}

The seed of D. indica was collected in August 2012 from Krabi Province, Thailand. The plant was identified by Pranom Chantaranothai, Faculty of Science, Khon Kaen University. A botanically identified voucher specimen (KKU0042012) was deposited at the herbarium of the Department of Chemistry, Faculty of Science, Khon Kaen University, Thailand.

\section{Extraction and isolation}

Air-dried seed $(5.8 \mathrm{~kg}$ ) of $D$. indica was ground and then extracted successively at room temperature with hexane $(2 \times 121)$, EtOAc $(2 \times 121)$, and $\mathrm{MeOH}$ $(2 \times 121)$. The filtered samples were combined, and the solvents were evaporated in vacuo to yield crude hexane (336 g), EtOAc (150 g), and $\mathrm{MeOH}(220 \mathrm{~g})$ extracts. The crude hexane extract (336 g) was subjected to silica gel flash column chromatography (FCC) and eluted with a gradient system of three solvents (hexane, EtOAc, and $\mathrm{MeOH}$ ) by gradually increasing the polarity of the elution solvents to give nine fractions, F1 to F9. F1 was identified as the natural oil (262.4 g, 5\% yield). Purification of F2 was carried out on silica gel FCC and eluted with the three gradient system above to give compound 8 (72.4 mg, 0.0012\%). The solid in fraction F5 was recrystallized from $\mathrm{CH}_{2} \mathrm{Cl}_{2}$ :EtOAc to give a colourless solid of compound $2(5.02 \mathrm{~g}, 0.0866 \%)$. The filtrate of F5 was evaporated to yield a viscous yellow oil, which was subjected to silica gel FCC using gradient elution of hexane:EtOAc mixtures to give six subfractions, F5.1-F5.6. Crystallization of subfraction F5.3 from EtOAc: $\mathrm{CH}_{2} \mathrm{Cl}_{2}$ gave a white solid of compound 4 (147 mg, 0.0025\%). Subfraction F5.5 was rechromatographed on silica gel FCC and eluted with an isocratic system of 10\% EtOAc:hexane to give four subfractions, F5.5.1-F5.5.4. Subfraction
F5.5.2 was purified by reversed-phase silica gel FCC using $25 \%$ water: $\mathrm{MeOH}$ as eluting solvent to give compound 10 (121.6 mg, 0.0021\%). Crystallization of subfraction F5.5.3 using EtOAc: $\mathrm{CH}_{2} \mathrm{Cl}_{2}$ yielded a colourless solid of compound $1(47.8 \mathrm{mg}$, $0.0008 \%$ ). The filtrate of F5.5.3 was purified by reverse-phase silica gel CC using $20 \%$ water:MeOH as eluting solvent to give compound $9(25.9 \mathrm{mg}$, $0.0004 \%)$ and compound 5 (4.3 mg, 0.0013\%). The purification of F8 by silica gel FCC and elution with hexane:EtOAc mixtures of increasing polarity gave six subfractions, F8.1-F8.6. Subfraction F8.1 was further purified by preparative TLC using $2 \%$ EtOAc:hexane as an eluting solvent to give compound 7 (35.3 $\mathrm{mg}, 0.0006 \%$ ). Subfraction F8.4 was rechromatographed on silica gel FCC and eluted with an isocratic system of $75 \% \mathrm{CH}_{2} \mathrm{Cl}_{2}$ :hexane to give compound 3 (11.4 mg, 0.0002\%). Subfraction F8.5 was subjected to silica gel FCC with $10 \%$ acetone:hexane to give seven subfractions, F8.5.1F8.5.7. Subfraction F8.5.1 was further purified by silica gel FCC using 10\% EtOAc:hexane as eluting solvent to give compound 11 (40.9 mg, 0.0007\%) and compound 6 (90.6 mg, 0.0016\%).

\section{Biological study}

AChE activity was evaluated by using the modified Ellman's spectrophotometric method. Tacrine was used as a reference standard. The assay was performed in 96-well plate by adding $25 \mu \mathrm{l}$ of $1 \mathrm{mM}$ acetylthiocholine iodide used as the substrate in the

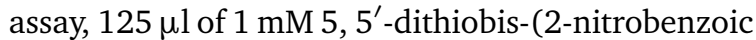
acid) (DTNB), $25 \mu \mathrm{l}$ of $0.1 \mathrm{M}$ phosphate buffer $\mathrm{pH} 7.4,25 \mu \mathrm{l}$ of testing substance in various concentrations and $50 \mu \mathrm{l}$ of 0.2 Units/ml AChE from an electric eel (type VI-S). At least five concentrations of the test compounds were assayed. The absorbance changes at $405 \mathrm{~nm}$ were detected every $30 \mathrm{~s}$ over a period of $5 \mathrm{~min}$ with a microplate reader. The enzyme activity and the percentage inhibition were determined ${ }^{9}$.

Cytotoxicity assays against human epidermoid carcinoma (KB) cell line was performed using the Resazurin Microplate Assay (REMA) ${ }^{10}$, and a cytotoxicity assay against Vero cells (African green monkey kidney) was performed using a Green Fluorescent Protein-(GFP-) based assay ${ }^{11}$. Ellipticine was included as a reference substance.

\section{RESULTS AND DISCUSSION}

Dry seed of $D$. indica $(5.8 \mathrm{~kg}$ ) was ground into powder and then extracted at room temperature with hexane, EtOAc, and $\mathrm{MeOH}$. The hexane 
<smiles>COc1ccc2c(=O)c(OC)c(-c3ccc4c(c3)OCO4)oc2c1</smiles><smiles>[R]c1ccc(-c2oc3c(cc([R])c4occc43)c(=O)c2[R])cc1[R]</smiles>

$2 \mathrm{R}^{1}=\mathrm{OCH}_{3}, \mathrm{R}^{2}=\mathrm{R}^{3}=\mathrm{R}^{4}=\mathrm{H}$ $3 R^{1}=R^{3}=R^{4}=H, R^{2}=\mathrm{OCH}_{3}$<smiles></smiles><smiles>COc1cc2c(c3c1C(=O)C(O)[C@H](c1ccccc1)O3)C=CC(C)(C)O2</smiles><smiles>COc1cc(OC)c2c(c1CC=C(C)C)C(=O)C[C@@H](c1ccccc1)O2</smiles><smiles>Cc1c(C(=O)/C=C(\O)c2ccccc2)ccc2occc12</smiles><smiles>COc1cc2c(c(O)c1C(=O)/C=C/c1ccccc1)C=CC(C)(C)O2</smiles><smiles>[R]c1ccc(/C=C/C(O)=C2C(=O)C(CC=C(C)C)(CC=C(C)C)C(=O)C=C2OC)cc1[R1]</smiles><smiles>COc1cc(OC)c(C(=O)/C=C/c2ccccc2)c(O)c1CC=C(C)C</smiles>
$10 \mathrm{R}^{1}=\mathrm{R}^{2}=\mathrm{H}$

Fig. 1 The structure of isolated compounds 1-11 from $D$. indica.

extracts were subjected to repeated column chromatography over silica gel, RP-18, preparative TLC to obtain 11 compounds. All isolated compounds were six flavonoids, desmethoxykanugin (compound 1$)^{5}$, karanjin (compound 2$)^{5}$, kanjone (compound 3$)^{12}$, pongaflavone (compound $4)^{13},(2 R, 3 R)$-3-hydroxy-5-methoxy- $2^{\prime \prime}, 2^{\prime \prime}$-dimethylpyrano $\left[7,8: 5^{\prime \prime}, 6^{\prime \prime}\right]$-flavanone (compound 5$)^{14}$, and candidone (compound 6$)^{15}$; and five chalcones, pongamol (compound 7) ${ }^{16}$, obovatachalcone (compound 8$)^{17}$, derrischalcone (compound 9$)^{18}$, tunicatachalcone (compound 10) ${ }^{19}$, and ovalichalcone (compound 11) ${ }^{20}$ (Fig. 1). The structures were elucidated by comparing their spectroscopic data with those reported in the literature. All compounds were evaluated for the inhibition of AChE using the modified Ellman's method and tested for cytotoxicity. The results are shown in Table 1.

Among the tested compounds, desmethoxykanugin (compound 1) showed the strongest inhibition to AChE (100\% inhibition) which is about two fold stronger than tacrine. However, this compound showed cytotoxic activity to normal cell (Vero cells) with $\mathrm{IC}_{50}$ value of $17.6 \mu \mathrm{g} / \mathrm{ml}$. Flavone compound 4 exhibited 56\% inhibition to AChE which was the same level as the standard tacrine while the flavones compound 2 and compound 3 showed weak activity.
It may be suggested that the pyran ring may play an important role in this activity. It was found that the flavanones compound 5 and compound 6 displayed about $50 \%$ inhibition which were the same level as tacrine. Fortunately, compound 4 and compound 5 showed inactive cytotoxic activity against Vero cells. This interesting information implied convincingly that the flavonoids compound 4 and compound 5 are useful lead compounds for the development of AChE inhibitors.

Table 1 AChE inhibitory and cytotoxicity of compounds from $D$. indica.

\begin{tabular}{lccc}
\hline Compound & $\begin{array}{c}\text { AChE inhibitory action } \\
(\% \text { inhibition) })^{\mathrm{a}, \mathrm{b}}\end{array}$ & \multicolumn{2}{c}{ Cytotoxicity $\mathrm{IC}_{50}(\mu \mathrm{g} / \mathrm{ml})^{\mathrm{a}}$} \\
\cline { 3 - 4 } & & $\mathrm{KB}$ & Vero cells \\
\hline 1 & $100.0 \pm 4.3$ & inactive & $17.6 \pm 0.8$ \\
2 & $1.9 \pm 0.7$ & inactive & inactive \\
3 & $3.1 \pm 1.8$ & inactive & inactive \\
4 & $55.9 \pm 3.2$ & inactive & inactive \\
5 & $58.3 \pm 6.7$ & inactive & inactive \\
6 & $55.9 \pm 5.5$ & $11.8 \pm 0.1$ & $6.4 \pm 0.2$ \\
7 & $58.8 \pm 3.2$ & $8.9 \pm 0.5$ & $4.2 \pm 0.1$ \\
8 & $60.3 \pm 4.4$ & $14.7 \pm 1.1$ & $5.2 \pm 0.6$ \\
9 & $2.6 \pm 1.2$ & $12.7 \pm 0.9$ & $4.3 \pm 0.9$ \\
10 & $1.5 \pm 1.0$ & $18.3 \pm 1.3$ & $7.3 \pm 0.4$ \\
11 & $4.6 \pm 1.1$ & inactive & inactive \\
tacrine & $54.7 \pm 3.4$ & & \\
ellipticine & - & $1.23 \pm 0.31$ & $1.27 \pm 0.28$ \\
\hline
\end{tabular}

${ }^{\text {a }}$ Data shown are from triplicate experiments.

b at $100 \mu \mathrm{M}$. 
Among chalcones, compound 7 and compound 8 showed stronger activity against AChE (around $60 \%$ inhibition) than compounds $9-11$. It seems that the presence of a furan or pyran group correlates with an increase in the activity. Unfortunately, compounds 7 and 8 exhibited cytotoxicity against Vero cells. In addition, compounds $6-10$ showed weak cytotoxicity against $\mathrm{KB}$ cell line.

There are many reports on the medicinal role of various plants for their neuroprotective properties by the active chemical constituents including alkaloids, steroids, terpenoids, saponins, phenolics, and flavonoids ${ }^{21}$. Phenolic compounds usually showed preventing the onset and progression of Alzheimer's disease ${ }^{22}$. In this study, six compounds including compounds 1 and 4-8 were found to be potent inhibitors against AChE activity. However, most of them (compounds 1,4-6) are flavonoids, two of them (compounds 7 and 8) are chalcones, and only one (compound 8) is a phenolic compound. These results showed that they are potent AChE inhibitors of flavonoids and chalcones groups as well.

In conclusion, the isolation and purification of compounds from the seed of $D$. indica led to six flavonoids and five chalcones. Among the isolated compounds, compound 1 displayed the strongest inhibition against AChE but it was not suitable to be used as AChE inhibitor due to strong cytotoxicity. Fortunately, compounds 4 and 5 inhibited AChE activity equally compared to the standard tacrine and showed no cytotoxicity.

Acknowledgements: We thank the Development and Promotion of Science and Technology Talents Project (DPST) for grant to T. Sribuhom. The Centre of Excellence for Innovation in Chemistry (PERCH-CIC), Office of the Higher Education Commission, Ministry of Education, Thailand, is gratefully acknowledged.

\section{REFERENCES}

1. Khoobi M, Ghanoni F, Nadri H, Moradi A, Hamedani MP, Moghadam FH, Emami S, Vosooghi M, et al (2015) New tetracyclic tacrine analogs containing pyrano[2,3-c]pyrazole: efficient synthesis, biological assessment and docking simulation study. Eur J Med Chem 89, 296-303.

2. Lan JS, Xie SS, Li SY, Pan LF, Wang XB, Kong LY (2014) Design, synthesis and evaluation of novel tacrine-( $\beta$-carboline) hybrids as multifunctional agents for the treatment of Alzheimer's disease. Bioorg Med Chem 22, 6089-104.

3. Anand P, Singh B (2013) A review on cholinesterase inhibitors for Alzheimer's disease. Arch Pharm Res 36, 375-99.
4. Rogers SL, Farlow MR, Doody RS, Mohs R, Friedhoff LT (1998) A 24-week, double-blind, placebo-controlled trial of donepezil in patients with Alzheimer's disease. Neurology 50, 136-45.

5. Koysomboon S, Altena I, Kato S, Chantrapromma K (2006) Antimycobacterial flavonoids from Derris indica. Phytochemistry 67, 1034-40.

6. Yadav PP, Ahmad G, Maurya R (2004) Furanoflavonoids from Pongamia pinnata fruits. Phytochemistry 65, 439-43.

7. Li L, Li X, Shi C, Deng Z, Fu H, Proksch P, Lin W (2006) Pongamone A-E, five flavonoids from the stems of a mangrove plant, Pongamia pinnata. Phytochemistry 67, 1347-52.

8. Sagwan S, Rao DV, Sharma RA (2010) Biochemical estimation of primary metabolites from Pongamia pinnata (L.): an important biodiesel plant. Int J Pharmaceut Sci Rev Res 5, 146-9.

9. Ellman GL, Courtney KD, Andres V Jr, Featherstone RM (1961) A new and rapid colorimetric determination of acetylcholinesterase activity. Biochem Pharmacol 7, 88-95.

10. Brien JO, Wilson I, Orton T, Pognan F (2000) Investigation of the Alamar Blue (resazurin) fluorescent dye for the assessment of mammalian cell cytotoxicity. Eur J Biochem 267, 5421-6.

11. Hunt L, Jordan M, De Jesus M, Wurm FM (1999) GFP-expressing mammalian cells for fast, sensitive, noninvasive cell growth assessment in a kinetic mode. Biotechnol Bioeng 65, 201-5.

12. Ganapaty S, Pushpalatha V, Babu GJ, Naidu KC, Waterman PG (1998) Flavonoids from Millettia peguensis Ali (Fabaceae). Biochem Systemat Ecol 26, 125-6.

13. Arriaga AMC, Lima JQ, Vasconcelos JN, de Oliveira MCF, Andrade-Neto M, Santiago GMP, Uchoa DEA, Malcher GT, et al (2009) Unequivocal assignments of flavonoids from Tephrosia sp. (Fabaceae). Magn Reson Chem 47, 537-40.

14. Stevensona PC, Kite GC, Lewis GP, Forest F, Nyirendac SP, Belmaina SR, Sileshi GW, Veitchb NC (2012) Distinct chemotypes of Tephrosia vogelii and implications for their use in pest control and soil enrichment. Phytochemistry 78, 135-46.

15. Blatt CTT, Chávez D, Chai H, Graham JG, Cabieses F, Farnsworth NR, Cordell GA, Pezzuto JM, et al (2002) Cytotoxic flavonoids from the stem bark of Lonchocarpus aff. fluvialis. Phytother Res 16, 320-5.

16. Tamrakar AK, Yadav PP, Tiwari P, Maurya R, Srivastava AK (2008) Identification of pongamol and karanjin as lead compounds with antihyperglycemic activity from Pongamia pinnata fruits. $J$ Ethnopharmacol 118, 435-9.

17. Chen YL, Wang YS, Lin YL, Munakata K, Ohta K (1978) Obovatin, obovatin methyl ether and obovatachalcone, new piscicidal flavonoids from Tephrosia obovata. Agr Biol Chem 42, 2431-2.

18. Decharchoochart P, Suthiwong J, Samatiwat P, 
Kukongviriyapan V, Yenjai C (2014) Cytotoxicity of compounds from the fruits of Derris indica against cholangiocarcinoma and HepG2 cell lines. $J$ Nat Med 68, 730-6.

19. Andrei CC, Ferreira DT, Faccione M, de Moraes LAB, de Carvalho MG, Braz-Filho R (2000) C-prenylflavonoids from roots of Tephrosia tunicata. Phytochemistry 55, 799-804.

20. Garcez FR, Scramin S, Nascimento MCD, Mors WB (1988) Prenylated flavonoids as evolutionary indicators in the genus Dahlstedtia. Phytochemistry 27, 1079-83.

21. Phani Kumar G, Anilakumar KR, Naveen S (2015) Phytochemicals having neuroprotective properties from dietary sources and medicinal herbs. $P h \operatorname{cog} J$ 7, $1-17$.

22. Pasinetti G (2016) Role of polyphenols in promotion of healthy brain aging and Alzheimer's disease preventative initiatives. In: Abstracts of Papers, 251st ACS National Meeting \& Exposition, San Diego, CA, pp 13-7. 